\title{
Weather Conditions Associated with the Release and Dispersal of Zymoseptoria tritici Spores in the Argentine Pampas Region
}

\author{
C. A. Cordo, ${ }^{1,2}$ C. I. Mónaco, ${ }^{1,2}$ R. Altamirano, ${ }^{3}$ A. E. Perelló, ${ }^{1,4}$ \\ S. Larrán, ${ }^{1}$ N. I. Kripelz, ${ }^{1,2}$ and M. R. Simón ${ }^{5}$ \\ ${ }^{1}$ Centro de Investigaciones de Fitopatología (CIDEFI-CIC), Facultad de Ciencias Agrarias y Forestales, \\ Universidad Nacional de La Plata, 60 y 119, Provincia de Buenos Aires, 1900 La Plata, Argentina \\ ${ }^{2}$ Comisión de Investigaciones Científicas de la Provincia de Buenos Aires (CIC), 1900 La Plata, Argentina \\ ${ }^{3}$ Curso de Bioestadística, Facultad de Ciencias Agrarias y Forestales, Universidad Nacional de La Plata, 60 y 119, \\ Provincia de Buenos Aires, 1900 La Plata, Argentina \\ ${ }^{4}$ Consejo Nacional de Investigaciones Científicas y Tecnológicas (CONICET), La Plata, Argentina \\ ${ }^{5}$ Curso de Cerealicultura, Facultad de Ciencias Agrarias y Forestales, Universidad Nacional de La Plata, Calle 60 y 119, \\ Provincia de Buenos Aires, 1900 La Plata, Argentina
}

Correspondence should be addressed to C. A. Cordo; cristcordo@gmail.com

Received 24 November 2016; Revised 4 March 2017; Accepted 9 April 2017; Published 13 June 2017

Academic Editor: Othmane Merah

Copyright (C) 2017 C. A. Cordo et al. This is an open access article distributed under the Creative Commons Attribution License, which permits unrestricted use, distribution, and reproduction in any medium, provided the original work is properly cited.

\begin{abstract}
The abundance of Zymoseptoria tritici ascospores and conidia in a field was examined throughout two one-year periods (19981999 and 1999-2000) establishing the relationship between spore release and weather variables. Radiation, temperature, intensity of rainfall, and relative humidity significantly affected the dispersal of ascospores and pycnidiospores of this pathogen. Spore traps collected both types of spores, at weekly intervals, at two different stages of the wheat crop (vegetative and wheat stubble stages) and different distances from the sources. Ascospores were the predominant sources of inoculum in the field. The numbers of ascospores and pycnidiospores declined with the increase of distance from the sources. The release of pycnidiospores was associated with the increase in rainfall intensity 7 days before the released event and the increase in radiation 60 days before the same event. Relative humidity 3 and 15 days before the release event was positively correlated with ascospores release and negatively correlated with radiation and temperature in all the sampling interval. Also for the first time, a positive correlation between radiation and pycnidiospores dispersal is reported. Understanding the relationship between environment conditions and spores dispersal event could improve the control strategies of the disease.
\end{abstract}

\section{Introduction}

In the rolling Pampas region of Argentina, conservation management practices such as zero tillage or reduced tillage have increased as alternative cropping systems to restore the soil structure in large areas cultivated with double-crop sequences or wheat monoculture [1]. In both systems, the inoculum of necrotrophic fungi usually survives until the next wheat growth season as potential inoculum of new pathogen infections.

In Argentina, one of the main foliar fungal diseases caused by a hemibiotrophic pathogen (a pathogen with an exceptionally long endophytic period for growth and acquisition of nutrients [2]) has historically been Zymoseptoria tritici (Desm.) Quaedvlieg \& Crous, a foliar pathogen of wheat, which causes Septoria Tritici Blotch (STB). This pathogen is only endemic in the Southeast of Buenos Aires Province. In other wheat cropping areas, its occurrence depends on the prevalent environment variables. The STB is an important wheat disease in the world that causes severe crop damage and substantial yield losses [3]. These effects are attributable to repeated cycles of the asexual stage of the fungus, in which pycnidia give rise to splash-dispersed pycnidiospores which eventually infect the upper leaves on whose photosynthetic 
activity crop yield is dependent. The movement of this type of spores was characterized by a vertical direction from the basal leaves to the highest leaves in the canopy that occurred during periods of splash rain and a horizontal movement between leaves close to each other, occurring without highenergy rainfall. Both mechanisms are most probably critical to disease progression [4].

The main source or primary inoculum for the infection of wheat by $Z$. tritici is the unburied crop residue [5]. Ascospores are produced and released on this substrate [6] and the fungus may complete several sexual cycles during the growing season. Pseudothecia mature during winter and remain viable into early spring. Only $30 \mathrm{~min}$ of moistening stubble is necessary for ascospore release and dispersal [7]. Hunter et al. [8] suggested that airborne ascospore plays the major role in epidemiology during the growing season and, together with splash dispersal spores, both have implications for the forecasting of the disease.

Different studies [5, 9] have confirmed that during spring and the beginning of summer the severity of the epidemic was conditioned by pycnidiospores produced in the crop; nevertheless, ascospores were present since the first basal leaves were infected [9, 10]. Carmona et al. [11] established that when effective management practices, including fungicide treatments, are applied under no-till systems in wheat monoculture, the occurrence of STB is possible without significant yield losses. The most effective fungicide applications are those applied between flag leaf emergence and the beginning of flowering [12]. In the climatic conditions of the rolling Pampas region of Argentina, growers are trained to apply foliar fungicides not preventively but only when the disease levels reach the threshold of economic damage [13]. Early monitoring of both types of spores and their relationship with climatic factors will allow knowing their dispersal cycle, which could be different between years. Moderate temperatures with alternating wet and dry periods were favorable for the production of pycnidiospores and ascospores [14].

Early spores monitoring of $Z$. tritici during the cycles of vegetative growth and stubble stage could be considered an indicator of risk for the occurrence of new infections. Hunter et al. [8] suggested that ascospores are dispersed in air currents rather than by rain splash, having important implications for risk-based decisions on disease control.

Different studies $[5,15,16]$ have confirmed that, during spring and the beginning of summer, the severity of an epidemic for this pathogen is conditioned by the number of pycnidiospores produced in the crop; nevertheless, ascospores are present from the time that the first basal leaves are infected [17].

The quantitative relationship between weather variables and the occurrence of $Z$. tritici has been reported by several authors. Pietravalle et al. [18] and Te Beest et al. [19] formulated an alternative model for early-warning of a damaging epidemic, based on accumulated rain and accumulated minimum temperature in the period preceding GS31 (tillering). In addition, the first authors indicated that the early phases of the epidemic were driven by temperature, which might determine the number of disease cycles that occurred in the following winter. Finally, in the UK, by studying a long period (1844-2003), Shaw et al. [20] confirmed that the diseases produced by $Z$. tritici and Parastagonospora nodorum are greatly influenced by the amount of spring rainfall and the previous summer temperature (for the period before the start of the growing season in autumn).

In Argentina, no studies about the release of spores of $Z$. tritici in the wheat growing cycle and the effect of weather variables on those patterns have been carried out.

The objective of this research was to quantify the presence of $Z$. tritici ascospores and conidia in a field of the rolling Pampas region of Argentina and to determine the relationship between variables like distance from the inoculum source, amount of rainfall, relative air humidity, air temperature and radiation, and both types of spores during a two one-year periods (1998-1999 and 1999-2000) in a warmer and cooler subperiod of a growing season, associating their release and dispersal.

\section{Materials and Methods}

2.1. Field Experiment. Field experiments were conducted in the East of the Pampas region at the Estación Experimental Julio Hirschhorn, located in Los Hornos (34.59 Lat. S., 57.59 Long W. Greenwich, Buenos Aires Province, Argentina), Facultad de Ciencias Agrarias y Forestales, Universidad Nacional de La Plata, Province of Buenos Aires.

The sampling of the spores was carried out from October 1998 to September 1999 and from October 1999 to September 2000 for the presence of wheat cultivars inoculated with the pathogen. The scores of trapped spores began in October of each year because the disease began to progress under favorable environmental conditions with the beginning of the stem elongation (GS, 37, Zadoks et al. [21]). The soil, where the cultivars were grown, was a Phaeozem luvico with a silt loam texture and slight internal drainage deficiency [22]. In the first period, the crop consisted of 50 national wheat (Triticum aestivum L.) cultivars with different susceptibility to the pathogen. The experiment was prepared as follows: wheat cultivars were sown on June 24, 1998, with a Deutz seed drill, at a density of 300 plants $/ \mathrm{m}^{2}$. The previous crops before this experiment were soybean (Glycine max (L.) Merr.) in 1993, corn (Zea mays L.) in 1994, and wheat from 1995 to 2000. Wheat was managed under conventional tillage by plowing twice and harrowing twice to a depth of $0.15 \mathrm{~m}, 9$ and 20 days before sowing, respectively. Wheat stubble was removed, chopped, and uniformly distributed on the soil surface. The experimental plots were situated in E-SE wind direction in the field and isolated $300 \mathrm{~m}$ from all other crops. An overview of the main dates of the experimental works is shown on Table 1.

2.2. Inoculation. Two inoculations of the wheat cultivars were done to obtain continuous sources of spores because this region is not endemic for the pathogen. For the inoculation process, a virulent isolate (FALP 3096; Facultad de Ciencias Agrarias y Forestales de la Plata, Argentina) of $Z$. tritici was used to prepare the inoculum. The isolate was grown on malt extract agar at $19^{\circ} \mathrm{C}$ with $12 \mathrm{~h}$ alternating light and dark 
TABLE 1: An overview of the main dates of the experimental works for 1998-1999 and 1999-2000 periods.

\begin{tabular}{|c|c|c|c|c|c|c|}
\hline \multicolumn{7}{|c|}{ 1998-1999 period } \\
\hline Activity & Sowing & Coleopt. emergency & Inoculation & Diseases & Assessment & Harvest \\
\hline Abbreviations & $S$ & $\mathrm{CE}$ & $\mathrm{i}$ & Boot B & Early dough grain ED & Ripening R \\
\hline GS (Zadoks et al. 1974) & 0 & 07 & 12 & 49 & 83 & 90 \\
\hline Dates & 29 June & 5 July & 12 July & 4 October & 22 November & 12 December \\
\hline \multicolumn{7}{|c|}{ 1999-2000 period } \\
\hline Activity & Sowing & Coleopt. emergency & Inoculation & Diseases & Assessment & Harvest \\
\hline Abbreviations & S & $\mathrm{CE}$ & $\mathrm{i}$ & Boot B & Early dough grain ED & Ripening R \\
\hline GS (Zadoks et al. 1974) & 0 & 07 & 12 & 49 & 83 & 90 \\
\hline Dates & 5 July & 23 July & 10 August & 20 October & 5 December & 20 December \\
\hline
\end{tabular}

1998-1999 period

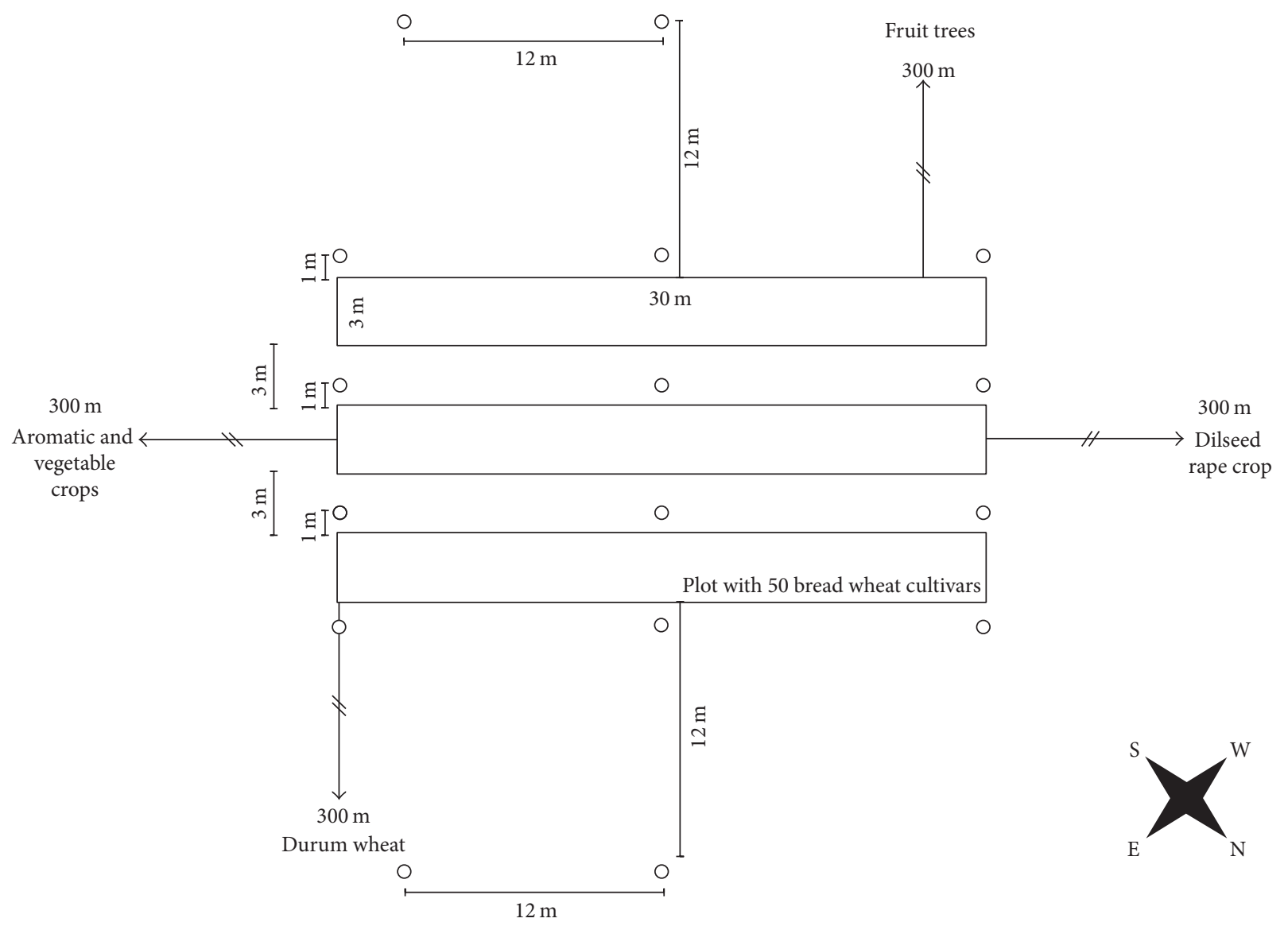

FIGURE 1: Spatial diagram of the traps arrangement: 1998-1999 period.

cycles. The inoculum was prepared by aseptically scraping sporulating colonies with a scalpel and suspending conidia in deionized water. The conidial suspension was adjusted to 5 $\times 10^{6}$ spores $/ \mathrm{mL}^{-1}$. The experimental plot was early infected by means of one inoculation at GS12 (first leaf extended) in July 1998.

The first symptoms of infection in the field were observed on the basal leaves on August 3, 1998, and the lesions were detected on flag leaf (FL) and FL-2 and FL-1 levels on October 4, 1998. At that moment (GS49), the severity of the disease ranged from 0.57 to 30.5 of mean pycnidial coverage percentage among all the cultivars, in coincidence with the placement of spore traps. The spore traps were placed following the diagram in Figure 1. The monitoring of both types of spores began one week later, in October 1998, and continued until September 1999 (first period) and then in the next year, from October 1999 to September 2000 (second period). The scores of trapped spores began in October of 
1999-2000 period
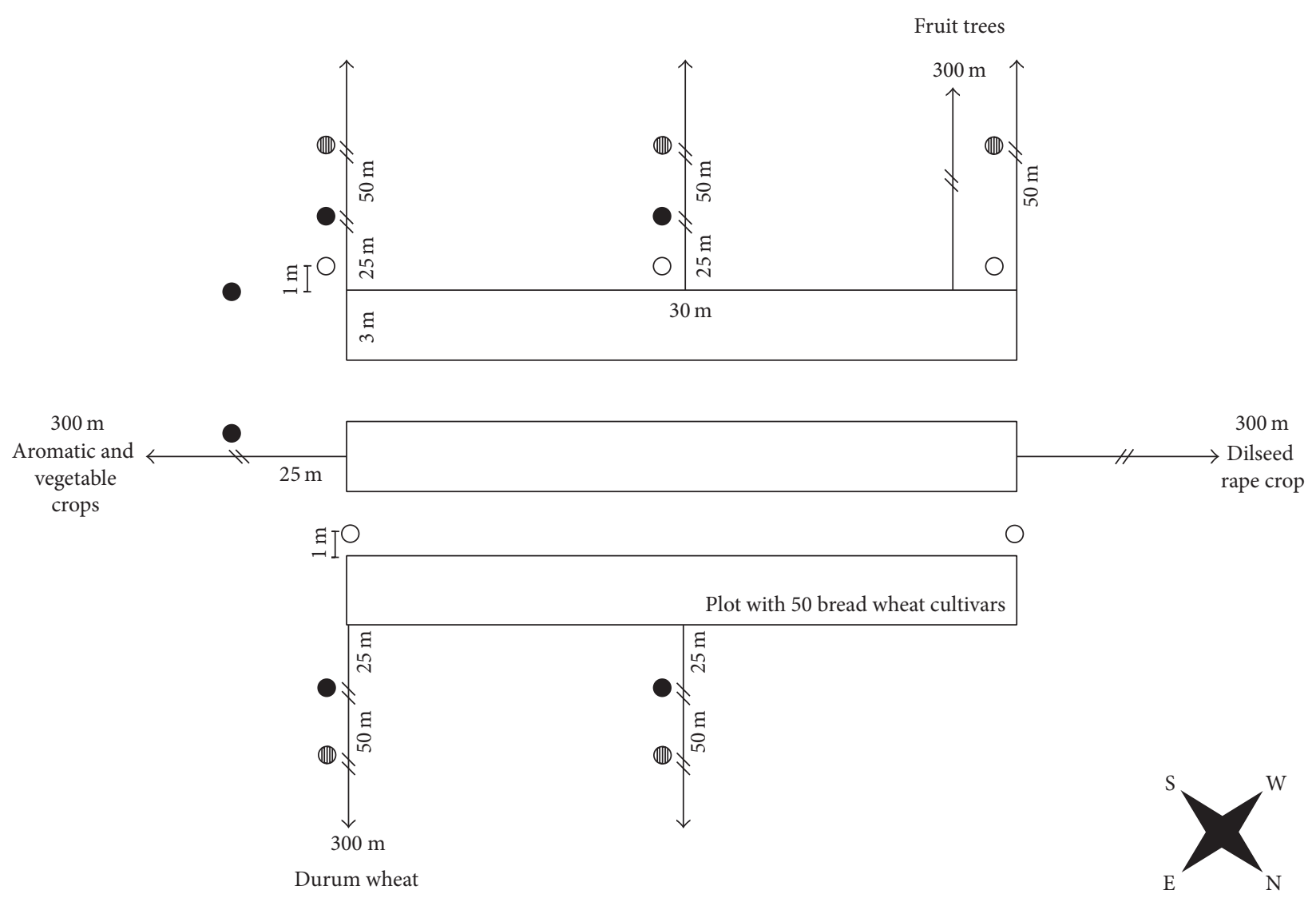

$$
\begin{aligned}
& \text { Distances } \\
& 1 \mathrm{~m} \\
& 25 \mathrm{~m} \\
& \text { III } 50 \mathrm{~m}
\end{aligned}
$$

FIGURE 2: Spatial diagram of the traps arrangement: 1999-2000 period.

each year because, under favorable conditions, the disease progresses from the beginning of the stem elongation (GS37) [21].

Ascospores were monitored only on Vaseline (AV), whereas pycnidiospores were monitored on Vaseline (PV) and rainwater (PRW). Spore traps were monitored once a week during the two periods.

In the second period, the source of inoculum consisted of 30 cultivars of national and Mexican germplasms of $T$. aestivum and T. durum with different levels of susceptibility, which were sown in the same experimental plot covered with the wheat stubble on July 5, 1999. In this period, the spore traps were placed following the diagram in Figure 2.

2.3. Spore Trapping. For both periods, sixteen spore traps were located close to and in a line parallel to the wide axis of the experimental plots. Considering that the predominant wind direction in the field was E-SE, for the first period, four traps were located in the center of the plots, four on the left side and four on the right, at $1 \mathrm{~m}$ of distance from the source of spores, orientated in the mentioned direction. Another four traps were situated at $12 \mathrm{~m}$ from that source. For the second period and considering that the difference between the results of those two distances from the first period was small, new distances were chosen: 1,25 , and $50 \mathrm{~m}$ from the source of spores. The traps, for the second period, were distributed as follows: five traps at $1 \mathrm{~m}$ surrounding the area from the source of inoculum, six traps in E-SE orientation, at $25 \mathrm{~m}$ from the source of inoculum, and six more traps covering the $\mathrm{N}-\mathrm{E}$ and E-SE directions at $50 \mathrm{~m}$.

The spore traps were made of PVC capsules, following the instructions of Góral and Arseniuk [23]. Each PVC capsule (a) was 20 and $24 \mathrm{~cm}$ in length in their minor and major axes and $11 \mathrm{~cm}$ in diameter. A rectangular wing (b) of $11 \times$ $14 \mathrm{~cm}^{2}$ suspended on a wood $\operatorname{rod}(\mathrm{c})$ of $32 \mathrm{~cm}$ in length with movement, containing slides (d) covered with Vaseline, was fixed to the front part of the capsule at $135^{\circ}$ (Figure 3 ).

The capsules were fixed $50 \mathrm{~cm}$ above the soil surface. Glass tubes (e) of $3 \mathrm{~cm}$ in diameter and $16 \mathrm{~cm}$ long were placed near the capsules to catch rain-splashed spores. Data 

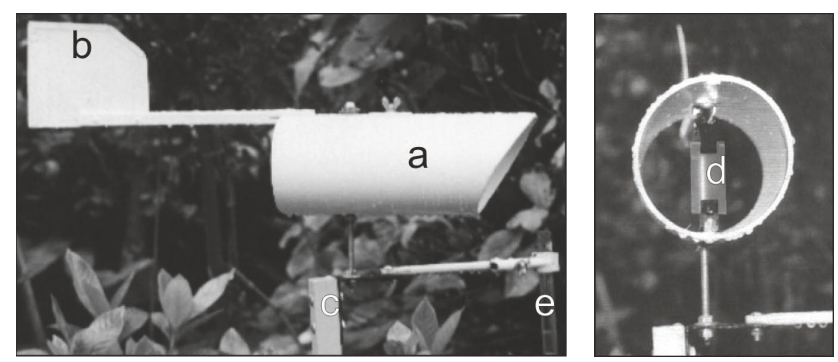

FIgure 3: Spore trap made in PVC. References: (a) PVC capsule; (b) rectangular wing; (c) wood rod; (d) slide covered with Vaseline fixed at $135^{\circ}$ to the front part of the capsule; (e) glass tube to collect rainwater.

on the number of pycnidiospores in rainwater (PRW) and in Vaseline (PV) and on the number of ascospores in Vaseline (AV) were recorded. The total sampled area reached $48 \mathrm{~m}^{2}$ in the first period and $150 \mathrm{~m}^{2}$ in the second period.

2.4. Microscopic Counts of Spores. The rain-splashed spores were identified by observation of the rainwater received in the glass tube and stained with an aniline blue (1/100) solution under the light microscope at 40x magnification. Fifty microliters of the stained suspension was poured on a glass slide and covered by a cover glass that enclosed an area of $40 \mathrm{~mm}^{2}$. Four counts (considering all the area of the cover glass) of the number of pycnidiospores were done on each sample per week. When the amount of water exceeded the volume of the tube, we took the following steps.

The tube for splashed spores had a volume of $65 \mathrm{~mL}$ of rainwater. If the rainfall during the day was higher than $30 \mathrm{~mL}\left(\mathrm{~mm}^{3}\right)$, the rainwater was collected two or three times, depending on the final volume of the rain. In this case, all the samples were considered as a single sample. Only the pycnidiospores with three-seven septa (mostly three) and with a size of $30-80 \times 1.5-2 \mu \mathrm{m}$ [24] were considered for counting.

For PV, the same decision as PRW was taken about the size range. For AV identification, only two-cell, elliptical, hyaline spores of 9-16 (18) $\times 2.5-4.5 \mu \mathrm{m}$ [7-25] were considered; the viability of the airborne spores was determined by recording their germination and formation of secondary conidia directly on Vaseline.

For counts of airborne pycnidiospores and ascospores, the slide glass covered by PV was stained with three drops of an aniline blue (1/100) solution and then covered by a cover glass that enclosed all the area of $119 \mathrm{~mm}^{2}$. The numbers of spores per slide, per week, were scored running all the cover glass area throughout five zig-zag pathways under a light microscope at 100x magnification. For the first period, 608 slides covered with Vaseline were checked to count pycnidiospores and ascospores; the same number of slides was checked to count spores in rainwater. For the second period, 684 slides covered with Vaseline were checked to count the same kind of spores as in the first period.
2.5. Meteorological Data. Meteorological data were recorded at the Meteorological Station situated close to the field experiments during 1998-1999 and 1999-2000. The weather variables and the intervals of time were selected from the results of consistent correlations obtained by other authors $[18,26,27]$. The following meteorological variables were considered: precipitation, as accumulated precipitation in $\mathrm{mm}$ of rainwater; the read value of precipitation, as $\mathrm{mm} / \mathrm{h}$ (intensity); the mean value of relative humidity, in \%; the mean radiation, in $\mathrm{W} \cdot \mathrm{m}^{-2}$; and the mean temperature, in ${ }^{\circ} \mathrm{C}$.

For each sampling data set and in accordance with the mean value of the spore catches at each distance, the mean value of each climatic variable and the sum of the data of each climatic variable at $3,7,15,30$, and 60 days before the sampling day were considered. No weather data were missing.

2.6. Data Analysis. The effects of the spore trapping and the distances from the inoculum sources were analyzed as follows. The average number of spores was transformed to logit. The data were adjusted to a normal distribution and the residual variance was stabilized. ANOVA with logarithmic transformation for a factorial experiment with replications was applied for each period (1998-1999 and 1999-2000). This transformation was performed to reduce the effect of extreme values and to make variances homogeneous. Factors were weeks and distances. The dispersal of spores throughout the weeks was described.

The data of the two periods were analyzed by nonparametric (Spearman's $r$ ) correlation analysis to confirm the dynamics of the different types of spores. To establish the relationship between the weather conditions and the dynamics of spores, we applied a principal component analysis (PCA) to the weekly values of the number of spores (PRW, PV, and $\mathrm{AV}$ ) collected at $1 \mathrm{~m}$ distance from the inoculum source and related them to the following variables: precipitation (as accumulated rainfall and intensity), relative humidity, radiation, and temperature $3,7,15,30$, and 60 days before the sampling date.

\section{Results}

3.1. Field Experiment. For both periods, the level of susceptibility of the national and international wheat cultivars sown in the field was high in $44 \%$ of them. Disease severity reached $40-50 \%$ for 1998 and $20-45 \%$ for 1999 , as mean of the pycnidial coverage percentage on the three upper leaves.

Data of spores quantified in the air and water were analyzed for each period separately because different distances from the source of inoculum were analyzed. For both periods, there were significant differences in the number of PRW, PV, and AV between weeks, distances (Tables 2 and 3) (Figures 5 and 6), and distance $\times$ weeks interaction. The mean number of spores sampled during the 1998-1999 period and at distances of $1 \mathrm{~m}$ and $12 \mathrm{~m}$ from the sources of inoculum was 4.80 and 2.61 for PRW, 10.28 and 7.23 for PV, and 18.88 and 6.17 for $\mathrm{AV}$, respectively, whereas that sampled during the 1999-2000 period and at distances of $1 \mathrm{~m}, 25 \mathrm{~m}$, and $50 \mathrm{~m}$ from the sources of inoculum was 3.32, 0.50 , and 0.20 for PRW, 
TABLE 2: ANOVA for ascospores on Vaseline (AV), pycnidiospores on Vaseline (PV), and pycnidiospores on rainwater (PRW) sampled at different distances and weeks during the first period (1998-1999).

\begin{tabular}{|c|c|c|c|c|c|c|c|c|c|}
\hline \multirow{2}{*}{ Source } & \multicolumn{3}{|c|}{ PRW } & \multicolumn{3}{|c|}{$\mathrm{PV}$} & \multicolumn{3}{|c|}{$\mathrm{AV}$} \\
\hline & MS & DF & $P$ value & MS & $\mathrm{DF}$ & $P$ value & MS & DF & $P$ value \\
\hline Distances & 14.51 & 1 & $0.000^{* * *}$ & 0.55 & 1 & 0.056 & 8.50 & 1 & $0.000^{* * *}$ \\
\hline Weeks & 6.89 & 51 & $0.000^{* * *}$ & 15.21 & 51 & $0.000^{* * *}$ & 10.39 & 51 & $0.000^{* * *}$ \\
\hline $\begin{array}{l}\text { Distances } \\
\times \text { weeks }\end{array}$ & 1.56 & 51 & $0.000^{* * *}$ & 2.75 & 51 & $0.000^{* * *}$ & 1.57 & 51 & $0.000^{* * *}$ \\
\hline Residual & 0.017 & 49 & & 0.25 & 49 & & 0.26 & 49 & \\
\hline
\end{tabular}

${ }^{* * *} P \leq 0.05$.

TABLE 3: ANOVA ascospores on Vaseline (AV), pycnidiospores on Vaseline (PV), and pycnidiospores on rainwater (PRW) sampled at different distances and weeks during the second period (1999-2000).

\begin{tabular}{|c|c|c|c|c|c|c|c|c|c|}
\hline \multirow{2}{*}{ Source } & \multicolumn{3}{|c|}{ PRW } & \multicolumn{3}{|c|}{ PV } & \multicolumn{3}{|c|}{$\mathrm{AV}$} \\
\hline & MS & DF & $P$ value & MS & $\mathrm{DF}$ & $P$ value & MS & $\mathrm{DF}$ & $P$ value \\
\hline Distances & 21.71 & 1 & $0.001^{* * *}$ & 24.15 & 1 & $0.001^{* * *}$ & 61.44 & 1 & $0.001^{* * *}$ \\
\hline Weeks & 8.62 & 51 & $0.001^{* * *}$ & 12.50 & 51 & $0.001^{* * *}$ & 24.24 & 51 & $0.001^{* * *}$ \\
\hline $\begin{array}{l}\text { Distances } \times \\
\text { weeks }\end{array}$ & 1.79 & 51 & $0.001^{* * *}$ & 1.70 & 51 & $0.001^{* * *}$ & 2.46 & 51 & $0.001^{* * *}$ \\
\hline Residual & 0.061 & 49 & & 0.071 & 49 & & 0.11 & 49 & \\
\hline
\end{tabular}

**** Mean significance at $P \leq 0.05$.

TABLE 4: Frequency of rain events corresponding to the peak of spores (PRW, PV, and AV) for the first period (1998-1999).

\begin{tabular}{|c|c|c|c|c|c|c|}
\hline & \multicolumn{6}{|c|}{$\begin{array}{c}\text { Number of days }{ }^{*}, \text { mm of rainfall }{ }^{* *} \text {, and relative humidity }(\mathrm{RH})^{* * *} \text { for the peak of each } \\
\text { kind of spores, date: } 20 \text { December } 1998\end{array}$} \\
\hline & $0 \mathrm{~mm}^{* *}$ & $0-0.9 \mathrm{~mm}$ & $1-9.9 \mathrm{~mm}$ & $\geq 10 \mathrm{~mm}$ & total & $\mathrm{RH}(\%)^{* * *}$ \\
\hline PRW & $14^{*}$ & 9 & 4 & 4 & 17 & 84 \\
\hline PV & 21 & 5 & 2 & 2 & 9 & 73.1 \\
\hline $\mathrm{AV}$ & 18 & 6 & 3 & 5 & 14 & 81.3 \\
\hline
\end{tabular}

${ }^{*}$ Values were taken 30 days before the occurrence of the rain event; ${ }^{* *} \mathrm{~mm}$ of rainfall; ${ }^{* * *}$ values were taken 3 and 15 days before the occurrence of the release event.

5.61, 1.69, and 0.94 for PV, and 20.09, 6.10, and 4.0 for $\mathrm{AV}$, respectively.

\subsection{Meteorological Data and Their Association with Each Kind} of Spores. In Figure 4 are represented the main parameters of the weather (mean values of rainfall, relative humidity, and temperature at weekly intervals) for 1998-1999 and 1999-2000 periods. The values of radiation were not considered because they are discontinued.

During the first period (Figure 5), the pycnidiospores were always present in both types of samples (RW and V).

The nonparametric (Spearman's $r$ ) correlation analysis showed that the pycnidiospores in rainwater and in Vaseline correlated positively and significantly at $5 \%(r=0.24805)$.

Regarding the frequency of rain events which occurred when we recorded the highest peaks of release for each type of spores (considering 30 days of observation), we recorded 17 events for PRW, 9 for PV, and 14 for AV. We also recorded the percentage of relative humidity for the same period (Table 4). In contrast, there was a negative and significant correlation at $5 \%(r=-0.153313)$ between AV and PV (Table 5).
TABLE 5: Correlation analysis (Spearman's $r$ ) between PRW, PV, and AV for the first period (1998-1999).

\begin{tabular}{lccc}
\hline Variables & PRW & PV & AV \\
\hline PRW & 1.000000 & $0.248050^{*}$ & $-0.153313^{*}$ \\
PV & $0.248050^{*}$ & 1.000000 & $-0.286511^{*}$ \\
AV & $-0.153313^{*}$ & $-0.286511^{*}$ & 1.000000 \\
\hline
\end{tabular}

${ }^{*}$ Correlations are significant at ${ }^{*} P<0.05$.

In the first period, most pycnidiospores in the air were produced and released between December 13 and December 21 although the first peak occurred between October 25 and November 22 and the second between March 10 and April 1 (Figure 5). With respect to AV, there were four peaks on July 13 and 27 and on August 24 and 31. PRW were always present in variable quantities; however, they were absent between January 17 and January 31.

In the second period, the weekly release of pycnidiospores was variable and, in contrast with the first period, it was 


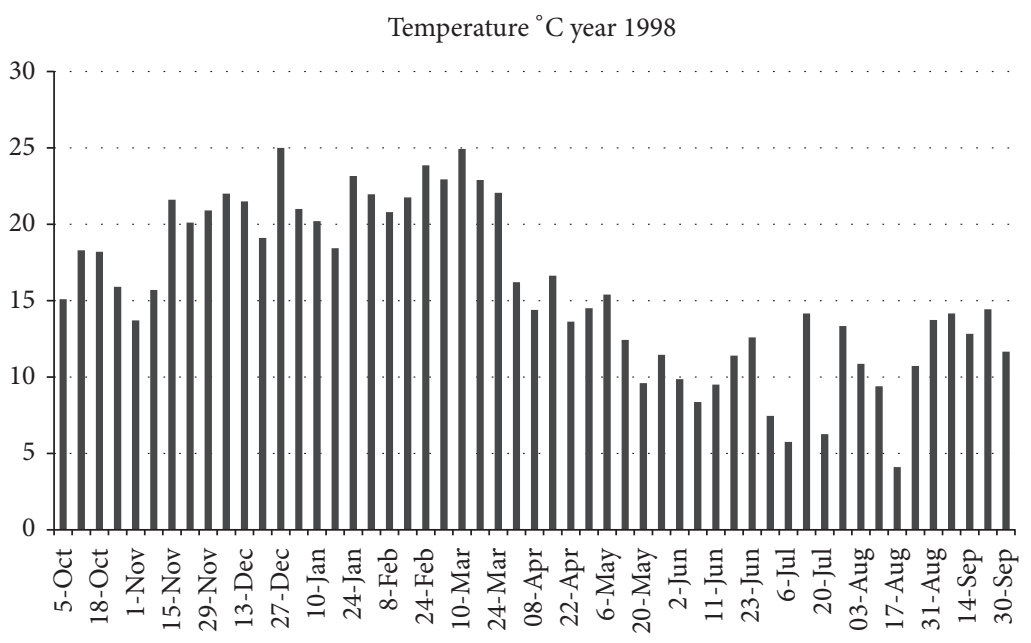

Temperature ${ }^{\circ} \mathrm{C}$ year 1998

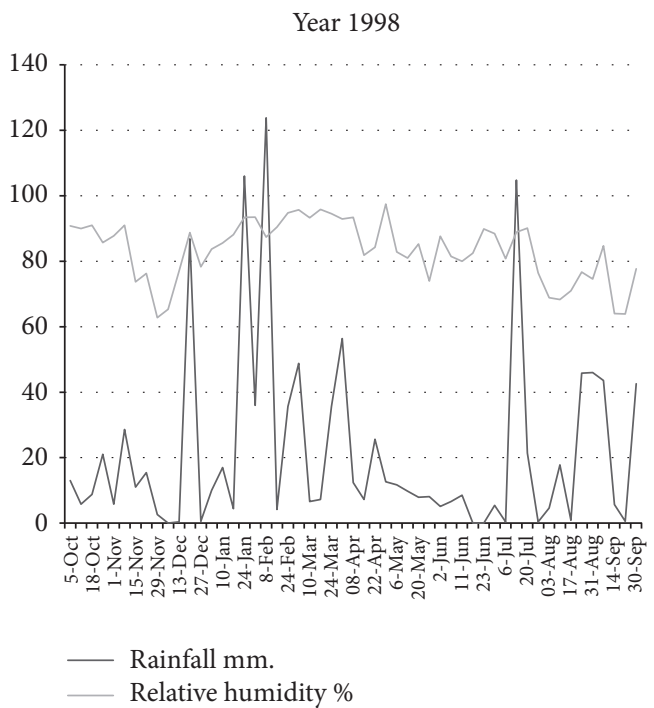

(a)

Temperature ${ }^{\circ} \mathrm{C}$ year 1999

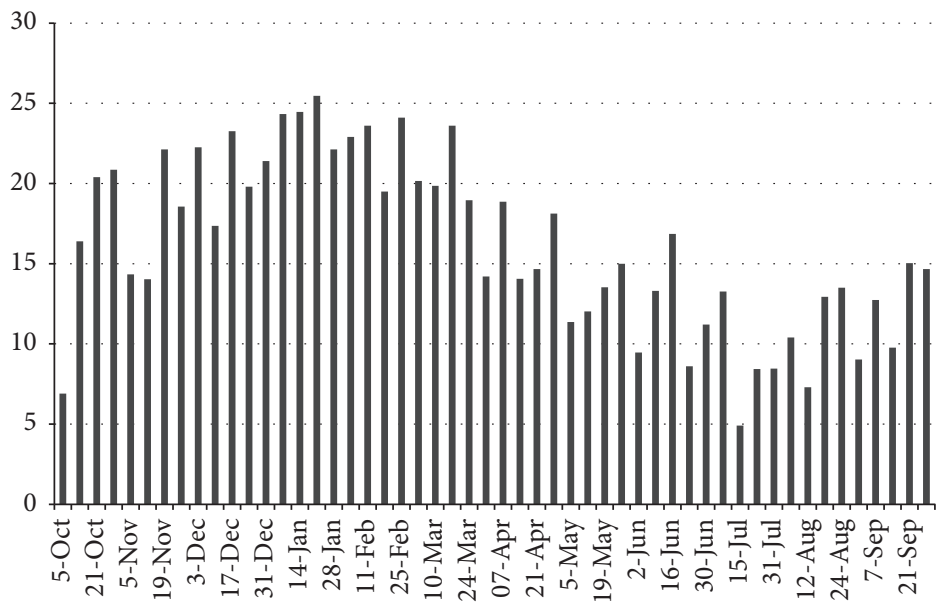

(b)
Year 1999

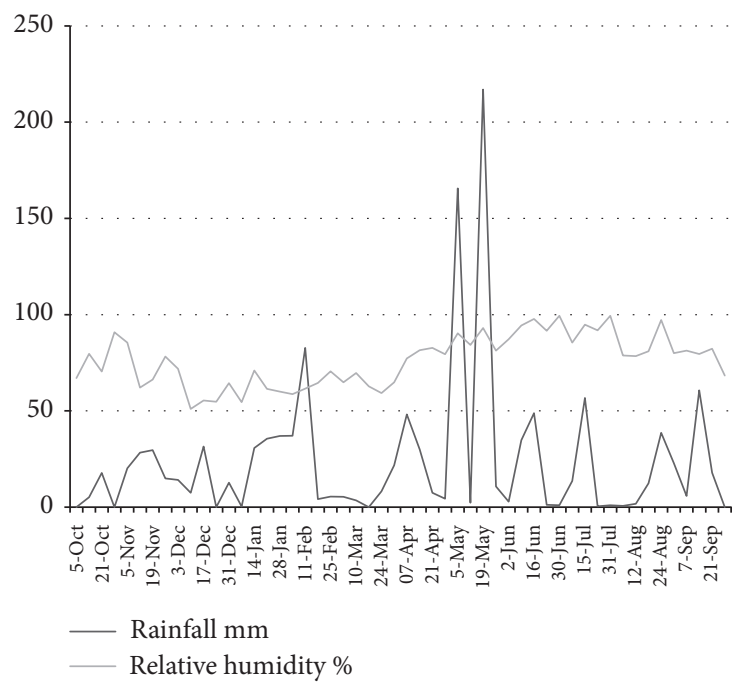

FIGURE 4: Main parameters of the weather (mean values of rainfall, relative humidity, and temperature at weekly intervals) for (a) 19981999 and (b) 1999-2000 periods. (a) 1998-1999 period = weather variables: rainfall in mm., relative humidity in \%, and temperature in ${ }^{\circ} \mathrm{C}$. (b)1999-2000 period $=$ weather variables: rainfall in mm., relative humidity in $\%$, and temperature in ${ }^{\circ} \mathrm{C}$.

lower in the number of units. However, the ascospores were the predominant source of inoculum. Figure 6 shows that there were two peaks of release of PRW on November 12 and November 26; three peaks of release of PV on February 11, May 5, and August 18; and seven peaks of release of AV on October 21, December 24, February 25, March 10 and 31, from April 14 to May 12, and on August 31. In relation to the frequency of rain events and coinciding with the highest peaks of release for each type of spores, in the second period and 30 days of observation, we recorded eight events for PRW, eight for PV, and 19 for AV (Table 6).

The number of PWR and PV correlated positively and significantly at $5 \%$, with a value of $r=0.109959$, whereas the number of PV and AV also correlated positively and significantly at $5 \%$, with a value of $r=0.275188$ (Table 7).

3.3. PCA Analysis. For the first period, the PCA showed two gradients formed by the environmental variables: the main sense from right to left, representing temperatures and radiation, and the diagonal sense from the right lower extreme towards the top left, representing rainfall.

By extrapolating the position of spores on these two gradients, we can see that AV appear to be associated with low values of temperature and radiation and that PRW and $\mathrm{PV}$ are associated with higher values of temperature and radiation. With regard to the gradient of precipitation, PV 
TABLE 6: Frequency of rain events corresponding to the peak of spores (PRW, PV, and AV) for the second period (1999-2000).

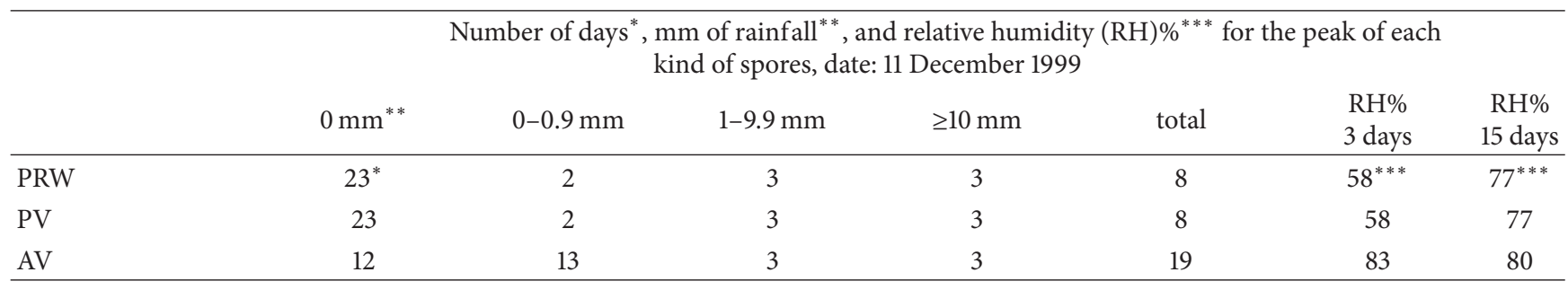

${ }^{*}$ Values were taken 30 days before the occurrence of the release event. ${ }^{* *} \mathrm{~mm}$ of rainfall. ${ }^{* * *}$ Values were taken 3 and 15 days before the occurrence of the release event.

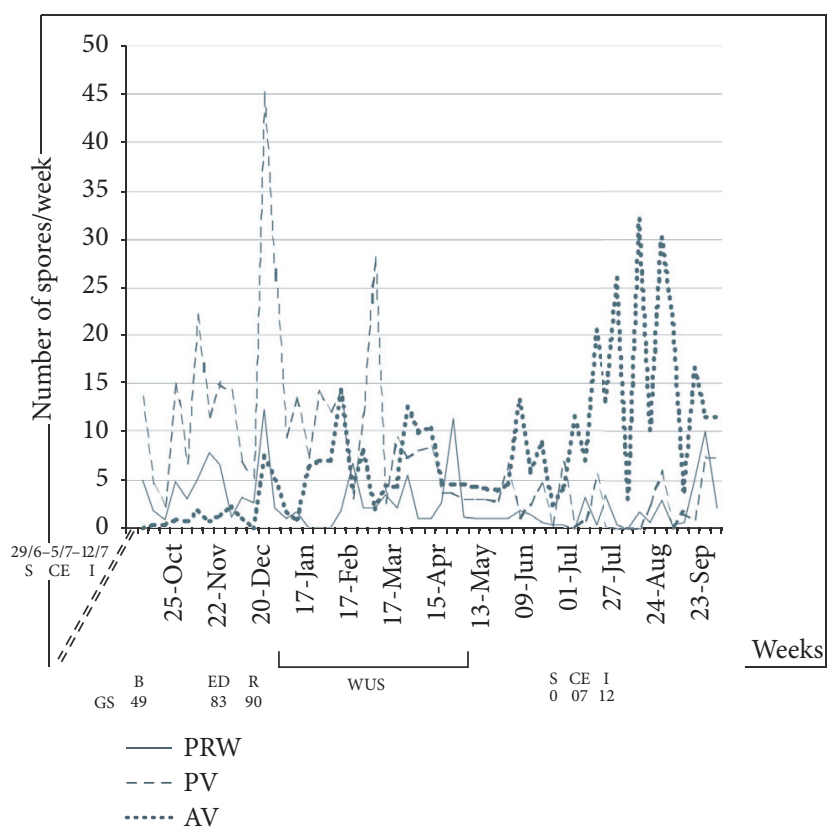

FIgURE 5: Number of PRW, PV, and AV of Zymoseptoria tritici during the first period. The wheat crop was harvested on December 20, 1998. References: type of spores: PRW: pycnidiospores in rain water; PV: pycnidiospores in Vaseline; AV: ascospores in Vaseline. Growth stages of wheat following Zadoks et al. 1974: S (sowing); CE (coleoptile emergency); i (inoculation); B (boot); ED (early dough grain); R (ripening); WUS (wheat unburied stubble); dates corresponding to each activity and growth stage in the field.

TABLE 7: Correlation analysis (Spearman's $r$ ) between PRW, PV, and AV for the second period (1999-2000).

\begin{tabular}{lccc}
\hline Variables & PRW & PV & AV \\
\hline PRW & 1.000000 & $0.109959^{*}$ & -0.078121 \\
PV & $0.109959^{*}$ & 1.000000 & $0.275188^{*}$ \\
AV & -0.078121 & $0.275188^{*}$ & 1.000000 \\
\hline
\end{tabular}

${ }^{*}$ Correlations are significant at $P<0.05$.

are located towards high values of rainfall and AV and PRW are located towards intermediate values. The main plane of analysis represents $53.8 \%$ of the total variation $(\mathrm{PCl}=34.49 \%$ and PC2 $=19.32 \%)$ (Figure 7).

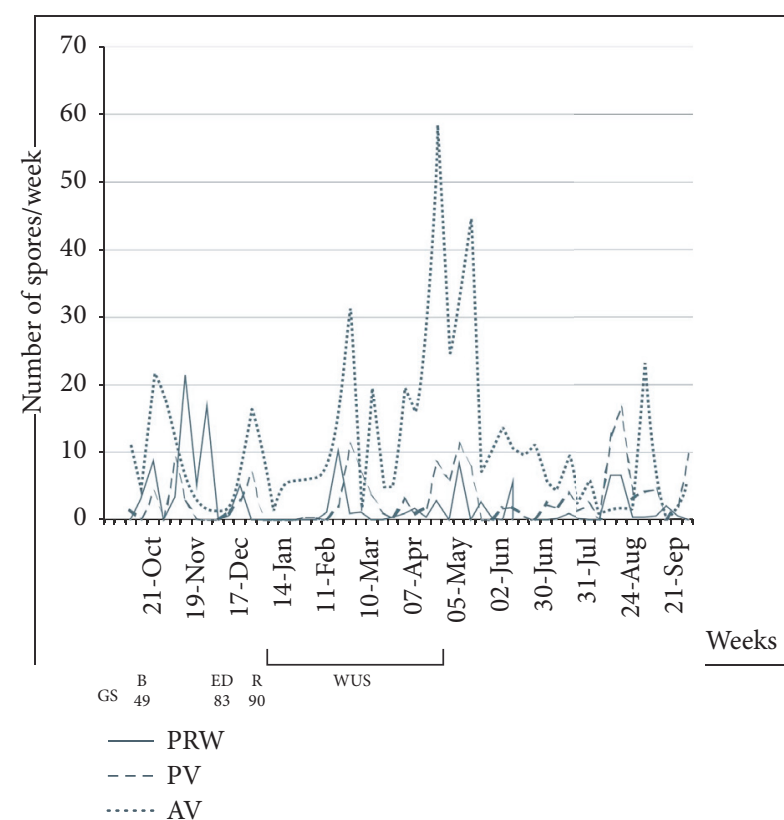

FIgURE 6: Number of PRW, PV, and AV of Zymoseptoria tritici during the second period. The wheat crop was harvested on December 18, 1999. References: type of spores: PRW: pycnidiospores in rain water; PV: pycnidiospores in Vaseline; AV: ascospores in Vaseline. Growth stages of wheat following Zadoks et al. 1974: S (sowing); CE (coleoptile emergency); i (inoculation); B (boot); ED (early dough grain); R (ripening); WUS (wheat unburied stubble); dates corresponding to each activity and growth stage in the field.

Table 8 shows the correlation matrix with the significant association between spores and the variables radiation and temperature.

For the second period, the PCA allowed identifying three gradients formed by environmental variables. PC1 from right to left represents temperatures and radiation, whereas that from left to right (discontinuous arrow) represents precipitation and relative humidity. In vertical direction, from the top to the bottom, the amount of precipitation increases (in $\mathrm{mm} / \mathrm{h}$ ). By extrapolating the position of spores on these three gradients, we see that PV and AV are associated with low values of temperature and radiation as well as with high values of rainfall and relative humidity and that PRW are mainly associated with high values of precipitation (in 


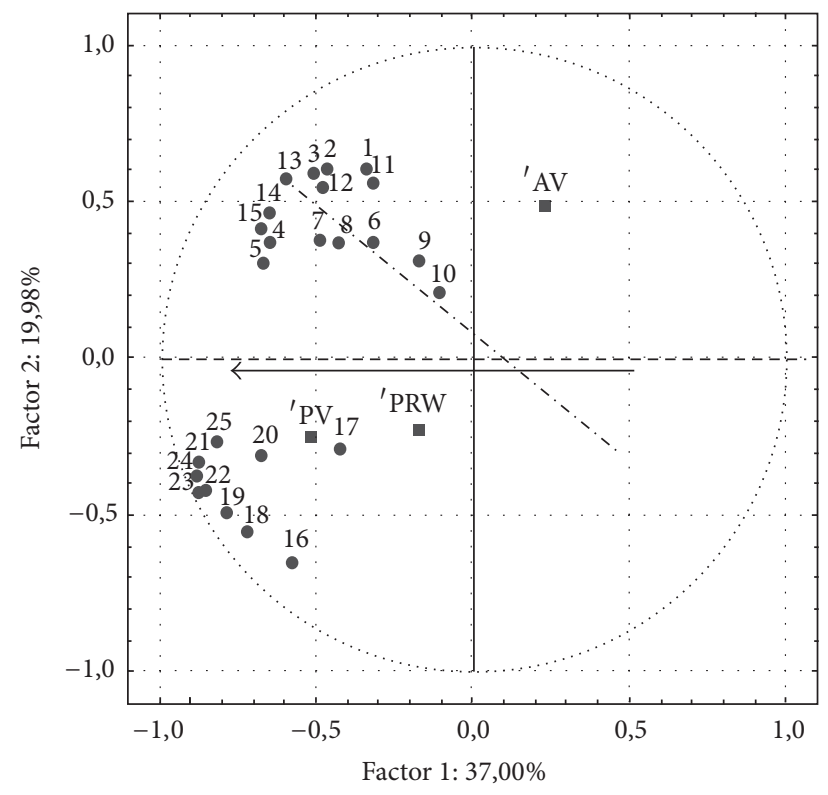

FIgURE 7: Correspondence analysis for pycnidiospores and ascospores of Zymoseptoria tritici in 1998-1999. Association between PRW, PV, AV, and weather variables as rainfall, relative humidity, radiation, and temperature $(3,7,15,30$, and 60 days before the sampling dates). References: PRW: pycnidiospores in rainwater; PV: pycnidiospores in Vaseline; $\mathrm{AV}$ : ascospores in Vaseline; numbers from 1 to 5 rainfall $(\mathrm{mm})$ at $3,7,15,30$, and 60 ; numbers 6 to 10 relative humidity (\%) at the same interval; numbers 11 to 15 rain intensity (I.mm/h.) at the same interval; numbers 16 to 20 radiation $\left(\mathrm{W} / \mathrm{m}^{2}\right)$ at the same interval; numbers 21 to 25 temperature $\left({ }^{\circ} \mathrm{C}\right)$ at the same interval.

$\mathrm{mm} / \mathrm{h})$. The main plane of analysis represents $55.85 \%$ of the total variation $(\mathrm{PC} 1=42.35 \%$ and $\mathrm{PC} 2=13.5 \%)$ (Figure 8 ).

Table 9 shows the correlation matrix with the significant association between spores and the variables precipitation, radiation, and temperature.

\section{Discussion}

Weather conditions, including critical variables as precipitation, air temperature, and solar radiation, have been related to $80 \%$ of the variation in agricultural production [28]. In this sense, the occurrence of plant diseases and the release of spores and dispersal of pathogens are relevant factors.

In the present study, in two one-year periods, with 52 weekly surveys per year, we analyzed a total of 1292 slides identifying AV and PV and 1292 slides identifying PRW. The magnitude of these observations enhances the coincidence of our results with those obtained by other authors $[4,8,18,19$, $23,26,27,29,30]$.

Trap spores made at home were user in this work. This spores sampler demonstrated important advantages with respect to that with a typical watch system (ex: Burkard spore trap). It is very economical to make (no more than 20 USD for each one), of simple maintenance through the years, and easy to build with elements of everyday use and enables designing an experiment with many repetitions easily

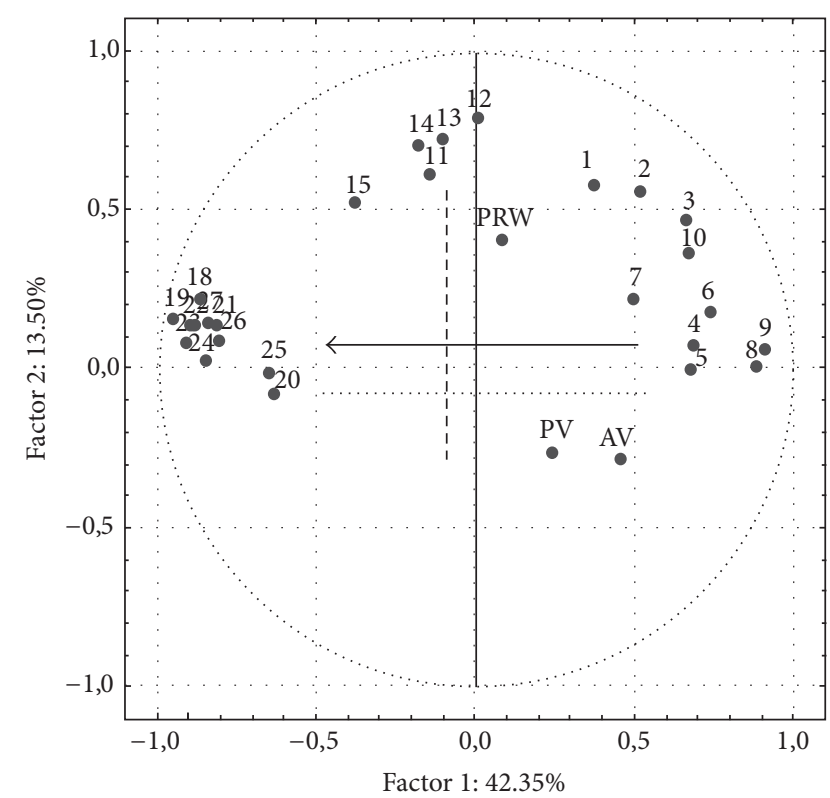

FIgURE 8: Correspondence analysis for pycnidiospores and ascospores in 1999-2000. Association between PRW, PV, AV, and weather variables as rainfall, relative humidity, radiation, and temperature $(3,7,15,30$, and 60 days before the sampling dates). References: PRW: pycnidiospores in rainwater; PV: pycnidiospores in Vaseline; AV: ascospores in Vaseline; numbers from 1 to 5 rainfall $(\mathrm{mm})$ at $3,7,15,30$, and 60 ; numbers 6 to 10 relative humidity (\%) at the same interval; numbers 11 to 15 rain intensity (I.mm/h.) at the same interval; numbers 16 to 20 radiation $\left(\mathrm{W} / \mathrm{m}^{2}\right)$ at the same interval; numbers 21 to 25 temperature $\left({ }^{\circ} \mathrm{C}\right)$ at the same interval.

allowing covering a wide surface area of the field. If all the parts of the trap are ready, in 8 hours per day, it is possible to assemble 10 samplers. This system of monitoring guaranteed to obtain comparable observations with those obtained by other authors $[4,8,18,19,23,26,27,29,30]$ affirming its use at experimental level.

In this work, we studied the weather variables associated with release and dispersal of the conidia and ascospores of the pathogen, both in the air and in the rainwater, under Buenos Aires province conditions. Both periods studied were climatically different, presenting extreme conditions of radiation and precipitation (as intensity) and minimum differences for temperature and relative humidity. For this reason, the correlation between weather variables and each kind of spores was different between years. In the present work and in accordance with Shaw and Royle [31], Kema et al. [32], and Hunter et al. [8], the trap dates clearly showed that ascospores were formed, released, and air-dispersed all year round for the two periods.

The fact that $Z$. tritici was not native to the crop and therefore was necessary to inoculate could explain a slow growth of ascospores in the air for the first period. This type of spores was increased in number for February of 1999 and predominated in abundance on winter of the same year.

Temperature and radiation seem in both periods to have the same effect on ascospores liberation. In both periods, 
TABLE 8: Correlation matrix of the number of PRW, PV, and AV and weather variables in the first period (1998-1999).

\begin{tabular}{|c|c|c|c|c|}
\hline & & Mean values of PRW & Mean values of PV & Mean values of AV \\
\hline & Mean of PRW & 1.00 & $0,46^{*}$ & $-0,17$ \\
\hline & Mean of PV & $0.46^{*}$ & 1,00 & $-0,25$ \\
\hline & Mean of AV & -0.17 & $-0,25$ & 1,00 \\
\hline 1 & Rain. 3 & -0.21 & 0,09 & 0,19 \\
\hline 2 & Rain. 7 & 0.09 & 0,28 & 0,23 \\
\hline 3 & Rain. 15 & 0.00 & 0,23 & 0,19 \\
\hline 4 & Rain. 30 & 0.13 & 0,15 & 0,13 \\
\hline 5 & Rain. 60 & 0.04 & 0.09 & 0.14 \\
\hline 6 & RH\% 3 & -0.01 & 0.04 & -0.19 \\
\hline 7 & RH $\% 7$ & 0.07 & 0.17 & -0.19 \\
\hline 8 & RH\% 15 & 0.06 & 0.12 & -0.22 \\
\hline 9 & RH\% 30 & 0.05 & -0.14 & -0.21 \\
\hline 10 & RH\% 60 & 0.17 & -0.19 & -0.22 \\
\hline 11 & I.mm/h 3 & -0.25 & 0.07 & 0.22 \\
\hline 12 & I.mm/h 7 & -0.02 & 0.24 & 0.19 \\
\hline 13 & I.mm/h 15 & -0.14 & 0.25 & 0.26 \\
\hline 14 & I.mm/h 30 & -0.08 & 0.10 & 0.28 \\
\hline 15 & I.mm/h 60 & -0.08 & 0.08 & 0.25 \\
\hline 16 & Rad. 3 & 0.28 & $0.51^{*}$ & $-0.41^{*}$ \\
\hline 17 & Rad. 7 & 0.06 & $0.48^{*}$ & -0.24 \\
\hline 18 & Rad. 15 & 0.28 & $0.61^{*}$ & $-0.46^{*}$ \\
\hline 19 & Rad. 30 & 0.28 & $0.65^{*}$ & $-0.46^{*}$ \\
\hline 20 & Rad. 60 & $0.29^{*}$ & $0.36^{*}$ & $-0.41^{*}$ \\
\hline 21 & Temp. 3 & 0.21 & $0.52^{*}$ & $-0.38^{*}$ \\
\hline 22 & Temp. 7 & 0.14 & $0.45^{*}$ & $-0.39^{*}$ \\
\hline 23 & Temp. 15 & 0.24 & $0.54^{*}$ & $-0.44^{*}$ \\
\hline 24 & Temp. 30 & 0.25 & $0.52^{*}$ & $-0.39^{*}$ \\
\hline 25 & Temp. 60 & 0.19 & $0.44^{*}$ & $-0.39^{*}$ \\
\hline
\end{tabular}

${ }^{*}$ Correlations are significant at $P<0.05$; Rain.: rainfall; Temp.: temperature; Rad.: radiation; I.mm/h: rain intensity in $\mathrm{mm} / \mathrm{h}$; RH\%: relative humidity in \%; AV: ascospores in Vaseline; PV: pycnidiospores in Vaseline; PRW: pycnidiospores in rain water; numbers from 1 to 5 rainfall ( $\mathrm{mm}$ ) at 3, 7, 15, 30, and 60; numbers 6 to 10 relative humidity (\%) at the same interval; numbers 11 to 15 rain intensity $\left(\mathrm{I} . \mathrm{mm} / \mathrm{h}\right.$.) at the same interval; numbers 16 to 20 radiation $\left(\mathrm{W} / \mathrm{m}^{2}\right)$ at the same interval; numbers 21 to 25 temperature $\left({ }^{\circ} \mathrm{C}\right)$ at the same interval.

the temperature decreased in autumn under a mean of $15^{\circ} \mathrm{C}$. Added to this, in the second period (1999-2000), the ascospores release was affected by the increase of the relative humidity (\%) from the beginning of summer to the end of autumn of 2000, when the crop stubble was in the field and influenced the beginning of the epidemic [14]. A new and moderate release was from the end of autumn to final of winter of the same year. The same result has been observed by several authors $[8,9,33,34]$. A negative correlation between the incidence of STB and the winter temperatures for Sweden conditions has been reported by Wiik and Ewaldz [35]. These authors affirmed that low temperatures during autumn and winter might delay the development of the disease by increased latent period and reduced ascospore production. The influence of radiation was also considered in the present study. Ascospore dispersal was associated with a decrease of radiation $3,7,15,30$, and 60 days prior to the date of ascospore release. In Netherlands, Daamen and Stol [10] reported a negative relationship between ascospore production and the sunshine duration in summer.
The presence of ascospores for 1998-1999 increased from the FL-1 and FL-2 stages till the occurrence of the new sown; for the second period, ascospores reached the maximum of release from the emergency of the wheat plants to boot stage and during the wheat stubble stage to the new sown in 2000 . This type of spores is equally effective in infecting the leaves $[15,16,18,19,34]$.

The proportion of pycnidiospores and ascospores in the air also depends on the infection level of the wheat varieties present in the field and the temporal dynamics of the diseases $[9,14,16]$. At the end of 1998 and the beginning of 1999, ascospores and pseudothecia coming from a large proportion of susceptible cultivars were an additional source of spores in the field [3].

The results of our work also highlight the importance of solar radiation and the intensity of the rain, besides the temperature and the relative humidity, cited by other authors $[4,18,19]$, in the release and dispersal of pycnidiospores.

The first event of pycnidiospores release occurred during 1998-1999 and was related to an intense rain, lasting as long 
TABLE 9: Correlation matrix of the number of PRW, PV, and AV and weather variables in the second period (1999-2000).

\begin{tabular}{|c|c|c|c|c|}
\hline & & Mean values of PRW & Mean values of PV & Mean values of $\mathrm{AV}$ \\
\hline & Mean of PRW & 1,00 & 0,05 & $-0,05$ \\
\hline & Mean of PV & 0,05 & 1,00 & $0,69^{*}$ \\
\hline & Mean of AV & $-0,05$ & $0,69^{*}$ & 1,00 \\
\hline 1 & Rain. 3 & 0,01 & $-0,15$ & $-0,10$ \\
\hline 2 & Rain. 7 & 0,17 & 0,06 & 0,15 \\
\hline 3 & Rain. 15 & 0,05 & 0,03 & 0,23 \\
\hline 4 & T. Rain. 30 & $-0,06$ & 0,07 & 0,15 \\
\hline 5 & T. Rain. 60 & $-0,04$ & $-0,02$ & 0,03 \\
\hline 6 & RH\% 3 & 0,02 & 0,16 & $0,42^{*}$ \\
\hline 7 & RH\% 7 & 0,10 & 0,20 & 0,32 \\
\hline 8 & RH\% 15 & 0,12 & $0,34^{*}$ & $0,44^{*}$ \\
\hline 9 & RH\% 30 & 0,20 & 0,24 & 0,32 \\
\hline 10 & $\mathrm{RH} \% 60$ & 0,29 & 0,05 & 0,04 \\
\hline 11 & I.mm/h 3 & 0,09 & $-0,34^{*}$ & $-0,29$ \\
\hline 12 & I.mm/h 7 & $0,54^{*}$ & $-0,12$ & $-0,13$ \\
\hline 13 & I.mm/h 15 & 0,27 & $-0,05$ & 0,03 \\
\hline 14 & I.mm/h 30 & 0,28 & 0,09 & $-0,09$ \\
\hline 15 & I.mm/h 60 & $-0,06$ & $-0,22$ & $-0,30$ \\
\hline 16 & Rad. 3 & 0,13 & $-0,15$ & $-0,45^{*}$ \\
\hline 17 & Rad. 7 & 0,15 & $-0,32$ & $-0,55^{*}$ \\
\hline 18 & Rad. 15 & 0,12 & $-0,27$ & $-0,55^{*}$ \\
\hline 19 & Rad. 30 & 0,04 & $-0,28$ & $-0,53^{*}$ \\
\hline 20 & Rad. 60 & $-0,08$ & 0,03 & $-0,20$ \\
\hline 21 & Temp. 3 & $-0,15$ & $-0,26$ & $-0,37^{*}$ \\
\hline 22 & Temp. 7 & $-0,19$ & $-0,21$ & $-0,38^{*}$ \\
\hline 23 & Temp. 15 & $-0,17$ & $-0,12$ & $-0,31$ \\
\hline 24 & Temp. 30 & $-0,16$ & $-0,04$ & $-0,26$ \\
\hline 25 & Temp. 60 & $-0,25$ & $-0,03$ & $-0,15$ \\
\hline
\end{tabular}

${ }^{*}$ Correlations are significant at $P<0.05$. Rain: rainfall; Temp.: temperature; Rad.: radiation; I.mm/h: rain intensity in mm/h; RH\% relative humidity in \%; AV: ascospores in Vaseline; PV: pycnidiospores in Vaseline; PRW: pycnidiospores in rain water; numbers from 1 to 5 rainfall ( $\mathrm{mm}$ ) at 3, 7, 15, 30, and 60; numbers 6 to 10 relative humidity (\%) at the same interval; numbers 11 to 15 rain intensity (I.mm/h.) at the same interval; numbers 16 to 20 radiation $\left(\mathrm{W} / \mathrm{m}^{2}\right)$ at the same interval; numbers 21 to 25 temperature $\left({ }^{\circ} \mathrm{C}\right)$ at the same interval.

as five hours without interruption (week of December 21 of 1998) (Figure 5). Eyal [36] explained that pycnidiospores are released from the cirrus after alternate cycles of moisture and dryness on pycnidia of the infected tissue. In this experiment, after a dry recovery period following a rain, a minimum of 7 hours of pycnidia wetting was necessary to release the spores. Pycnidiospores liberation correlated differentially for both periods. For 1998-1999, the liberation was positively associated with radiation and temperature. From 5 October 1998 to 8 April 1999, the temperature was predominant with mean values of $15-25^{\circ} \mathrm{C}$. During this period, the pycnidiospores were abundant from boot to grain ripening stages of wheat. On the contrary, for 1999-2000, pycnidiospores positively correlated with relative humidity where the values in percentage were $50-80 \%$, from October to December, and 70-100\% in the period April-September 2000. Our results are in agreement with those of Chungu et al. [37] and Te Beest et al. [19], who demonstrated that long periods of humidity influence the latent period of spore production in the pathogen and later spore release.
A positive and significant correlation with rain intensity (I.mm/h) 7 days before the release event was confirmed for pycnidiospores collected in rainwater (PRW). More rain produces spores that move to uninfected plant surfaces in splash droplets and lead to more production of conidia for a next infection within a crop [19]. Our observations are in agreement with field observations of Shaw [38]. This author expressed that a sudden outbreak of $Z$. tritici lesions in a wheat crop was related to a great upward transport of rain splash 21 days before the emergence of lesions. The author added that the risk of infection within a crop is partly determined by the distance to which splash droplets move. In other words, the rate at which disease spreads out from the infected plants will be determined by the average horizontal distance moved by spore-carrying raindrops and the height above the sources of spores. Also, Rapilly and Jolivet [39] related the drop size and the rainfall intensity with the height to which inoculum splash was projected. Brennan et al. [40] measured the number of splash droplets collected at different heights and established that the most relevant number of 
raindrops during a rainfall was found at $20 \mathrm{~cm}$ horizontally away from the source of conidia and was associated with a rainfall rate of $1.0 \mathrm{~mm} / \mathrm{min}$. Extremely large and nonfrequent droplets that were found at $50 \mathrm{~cm}$ horizontally away were associated with a rainfall rate of $4.7 \mathrm{~mm} / \mathrm{min}$ but such large drops cannot be the dominant component of most rain.

During 1999-2000, some picks of rainfall were registered from 11 February to 21 September of 2000. From tillering to boot stages, pycnidiospores number increased in constant way parallel to ascospores doubling the number of effective infections. In agreement with that found by Lutey and Fezer [41], pycnidiospores are especially abundant when the stubble is laid on the ground, for example, between March and April of 2000 for our experimental conditions. In this period, when the temperature increased above $14^{\circ} \mathrm{C}$ and the radiation was between 4264 and $5840 \mathrm{~W} \cdot \mathrm{m}^{-2}$, the leaf wetness was reduced (data not shown). Te Beest et al. [19] added that short periods of leaf wetness are unfavorable for the latent period of the pathogen, affecting spore production and dispersal. Our results clearly showed that radiation, temperature, precipitation (as intensity), and relative humidity significantly affected the dispersal of ascospores and pycnidiospores of Z. tritici. In addition, we demonstrated that pycnidiospores and ascospores were released throughout the year. The predominance of each type of spore in the air was associated with the weather variables occurring during each stage of the wheat crop (vegetative or wheat debris stages). The release of ascospores was associated with low values of temperature and radiation, whereas that of pycnidiospores was associated with high values of both variables. The pycnidiospores caught in water were mainly associated with a high intensity of precipitation $(\mathrm{mm} / \mathrm{h})$.

Understanding the relationship between environment conditions and spores dispersal event could improve the control strategies of the disease.

\section{Conflicts of Interest}

The authors declare that they have no conflicts of interest.

\section{Acknowledgments}

This research received financial support from CIC (Exp. 2157-71 9/03, 2157-125/04, 2157-1994/05, 2157-3090/7) and CONICET PICT 99 (08-06356 A). The first author thanks specially her father, Mr. Benigno R. Cordo $(\dagger)$, and dedicates this paper to him for his enthusiastic work making the spore traps; many thanks are due to the farm staff at Los Hornos Experimental Station, especially Ing. Agr. Martin Pardi for his assistance on management of the meteorological dates and for maintaining field trials and Miss Eugenia Balonga and Miss Mariana Ezquiaga for their assistance with graphics.

\section{References}

[1] R. Alvarez and H. S. Steinbach, "A review of the effects of tillage systems on some soil physical properties, water content, nitrate availability and crops yield in the Argentine Pampas," Soil and Tillage Research, vol. 104, no. 1, pp. 1-15, 2009.
[2] A. Sánchez-Vallet, M. C. McDonald, P. S. Solomon, and B. A. McDonald, "Is Zymoseptoria tritici a hemibiotroph?" Fungal Genetics and Biology, vol. 79, pp. 29-32, 2015.

[3] M. R. Simón, A. E. Perelló, C. A. Cordo et al., "Association between septoria tritici blotch, plant height, and heading date in wheat," Agronomy Journal, vol. 97, no. 4, pp. 1072-1081, 2005.

[4] D. J. Lovell, S. R. Parker, T. Hunter, D. J. Royle, and R. R. Coker, "Influence of crop growth and structure on the risk of epidemics by Mycosphaerella graminicola (Septoria tritici) in winter wheat," Plant Pathology, vol. 46, no. 1, pp. 126-138, 1997.

[5] W. Schuh, "Influence of tillage systems on disease intensity and spatial pattern of Septoria leaf blotch," Phytopathology, vol. 80, pp. 1337-1340, 1990.

[6] G. Shaner, "Effect of environment on fungal leaf blights of small grains," Annual Review of Phytopathology, vol. 19, pp. 273-296, 1981.

[7] F. R. Sanderson, "A Mycosphaerella species as the ascogenous state of Septoria tritici rob. and Desm," New Zealand Journal of Botany, vol. 10, no. 4, pp. 707-709, 1972.

[8] T. Hunter, R. R. Coker, and D. J. Royle, “The teleomorph stage, Mycosphaerella graminicola, in epidemics of Septoria tritici blotch on winter wheat in the UK," Plant Pathology, vol. 48, no. 1, pp. 51-57, 1999.

[9] C. A. Cordo, M. R. Simón, A. E. Perello, and H. E. Alippi, "Spore dispersal of leaf blotch of wheat Mycosphaerella graminicola and Septoria tritici," in Septoria aNd Stagonospora Diseases of Cereals. A Compilation of Global Research, M. van Ginkel, A. McNab, and J. Krupinsky, Eds., pp. 98-101, CIMMYT, Ciudad de Mexico, D.F., Mexico, 1999.

[10] R. A. Daamen and W. Stol, "Survey of cereal diseases and petts in the Netherlands. Occurrence of Septoria spp. in winter wheat," Netherlands Journal of Plant Pathology, vol. 98, no. 6, pp. 369376, 1992.

[11] M. Carmona, E. Reis, and P. Cortese, Leaf Spot of Wheat Diagnosis, Epidemiology And New Approache to The Managemnent, BASF, Buenos Aires, Argentina, 1999.

[12] E. D. De Wolf and S. A. Isard, "Disease cycle approach to plant disease prediction," Annual Review of Phytopathology, vol. 45, pp. 203-220, 2007.

[13] A. N. Formento and L. S. Schutt, "Monitoreo, perfil sanitario, factores climáticos y toma de decisiones en el manejo de la roya de la hoja y mancha amarilla del trigo," in Jornada Regional de Cultivos de Invierno, pp. 61-67, Campaña, spain, 2012.

[14] F. Suffert and I. Sache, "Relative importance of different types of inoculum to the establishment of Mycosphaerella graminicola in wheat crops in north-west Europe," Plant Pathology, vol. 60, no. 5, pp. 878-889, 2011.

[15] L. Eriksen and L. Munk, "The occurrence of Mycosphaerella graminicola and its anamorph Septoria tritici in winter wheat during the growing season," European Journal of Plant Pathology, vol. 109, no. 3, pp. 253-259, 2003.

[16] M. Duvivier, G. Dedeurwaerder, M. De Proft, J.-M. Moreau, and A. Legrève, "Real-time PCR quantification and spatiotemporal distribution of airborne inoculum of Mycosphaerella graminicola in Belgium," European Journal of Plant Pathology, vol. 137, no. 2, pp. 325-341, 2013.

[17] C. A. Cordo, M. R. Simón, A. E. Perelló, D. Bayo, N. Kripelz, and S. Larrán, "Environmental factors affecting the release and dispersal of pycnidiospores and ascospores of Mycosphaerella graminicola," in Proceedings of the 7th International Wheat Conference Abstracts, p. 131, Mar del Plata, Argentina, 2005. 
[18] S. Pietravalle, M. W. Shaw, S. R. Parker, and F. van den Bosch, "Modeling of relationships between weather and Septoria tritici epidemics on winter wheat: a critical approach," Phytopathology, vol. 93, no. 10, pp. 1329-1339, 2003.

[19] D. E. Te Beest, M. W. Shaw, S. Pietravalle, and F. Van Den Bosch, "A predictive model for early-warning of Septoria leaf blotch on winter wheat," European Journal of Plant Pathology, vol. 124, no. 3, pp. 413-425, 2009.

[20] M. W. Shaw, S. J. Bearchell, B. D. L. Fitt, and B. A. Fraaije, "Longterm relationships between environment and abundance in wheat of Phaeosphaeria nodorum and Mycosphaerella graminicola," New Phytologist, vol. 177, no. 1, pp. 229-238, 2008.

[21] J. C. Zadoks, T. T. Chang, and C. F. Konzak, "A decimal code for the growth stages of cereals," Weed Research, vol. 14, no. 6, pp. 415-421, 1974.

[22] J. V. Gil, Atlas de Suelos de la República Argentina, Buenos Aires: INTA, Soils Atlas, Argentina, 1990.

[23] T. Góral and E. Arseniuk, "Effect of climatic conditions on liberation and dispersal of spores of Leptosphaeria spp. in the air," Phytopathology Polónica, vol. 2, pp. 28-34, 1991.

[24] P. R. Scott, F. R. Sanderson, and P. W. Benedikz, "Occurrence of Mycosphaerella graminicola, teleomorph of Septoria tritici, on wheat debris in the UK," Plant Pathology, vol. 37, no. 2, pp. 285290, 1988.

[25] C. Cordo, A. Perelló, H. Alippi, and H. Arriaga, "Presencia de Mycosphaerella graminicola (Fuckel) Schroeter teleomorfo de Septoria tritici; Rob apud Desm. en trigos maduros de la Argentina," Revista de la Facultad de Agronomia, vol. 66/67, pp. 49-55, 1990-1991.

[26] W. Shaner and R. Finney, "Weather and epidemics of septoria leaf blotch of wheat," Phytopathology, vol. 66, no. 6, pp. 781-785, 1976.

[27] A. Bahat, G. Ilana, M. B. Brown, and Z. Eyal, "Factors affecting the vertical progression of Septoria leaf blotch in short stature wheats," Phytopathology, vol. 70, no. 3, pp. 179-184, 1980.

[28] L. Wiik, "Aderleken och Septoria spp.: Sambandet mellanmnagra klimatparametraroch skorderforlusten orsakad av Septoria spp," Evenskavsxstkyddskonferensen. Skadedjuroch vaxtsjukdomar, vol. 34, pp. 85-90, 1993.

[29] S. M. Coakley, L. R. McDaniel, and G. Shaner, "Model for predicting severity of Septoria tritici blotch on winter wheat," Phytopathology, vol. 75, no. 11, pp. 1245-1251, 1985.

[30] T. Góral and E. Arseniuk, “The study of relationship between distance from a point inoculum source, wheather variables and the air presence of Phaeosphaeria spp. ascospores in warmer and cooler sub-periods of a growing season," Plant Breeding And Seed Science, vol. 2, pp. 208-214, 1998.

[31] M. W. Shaw and D. J. Royle, "An epidemiology based forecasting scheme for Septoria tritici," in Proceeding of the 3rd International Workshop of Septoria Diseases of Cereals, P. M. Fried, Ed., pp. 107-109, 1989.

[32] G. H. Kema, E. C. Verstappen, M. Todorova, and C. Waalwijk, "Successful crosses and molecular tetrad and progeny analyses demonstrate heterothallism in Mycosphaerella graminicola," Current Genetics, vol. 30, no. 3, pp. 251-258, 1996.

[33] L. Eriksen, The influence of sexual reproduction on the structure of populations of Mycosphaerella graminicola in relation to durability of resistance [Ph.D. thesis], The Royal Veterinary and Agricultural University, Frederiksberg C, Denmark, 2000.

[34] L. Eriksen, M. W. Shaw, and H. Ostergard, "Model of the effect of pseudothecia on genetic recombination and epidemic development in populations of Mycosphaerella graminicola," Phytopathology, vol. 91, p. 519, 2001.

[35] L. Wiik and T. Ewaldz, "Impact of temperature and precipitation on yield and plant diseases of winter wheat in southern Sweden 1983-2007," Crop Protection, vol. 28, no. 11, pp. 952-962, 2009.

[36] Z. Eyal, "Kinetic of pycnidiospores liberation in Septoria tritici," Canadian Journal of Botany, vol. 49, pp. 1095-1099, 1971.

[37] C. Chungu, J. Gilbert, and F. Townley-Smith, "Septoria tritici blotch development as affected by temperature, duration of leaf wetness, inoculum concentration, and host," Plant Disease, vol. 85 , no. 4, pp. 430-435, 2001.

[38] M. W. Shaw, "Assessment of upward movement of rain splash using a fluorescent tracer method and its application to the epidemiology of cereal pathogens," Plant Pathology, vol. 36, no. 2, pp. 201-213, 1987.

[39] F. Rapilly and E. Jolivet, "Construction d'un modéle (EPISEPT) permettent la simulation d' une épidemie de Septoria nodorum Berk. Sur blé," Revue de Statistique Appliquée, vol. 24, pp. 31-60, 1976.

[40] R. M. Brennan, B. D. Fitt, G. S. Taylor, and J. Colhoun, "Dispersal of Septoria nodorum pycnidiospores by simulated raindrops in still air," Journal of Phytopathology, vol. 112, no. 4, pp. 281-290, 1985.

[41] R. W. Lutey and K. D. Fezer, "The role of infested straw in the epiphytology of Septoria leaf blotch of barley," Phytopathology, vol. 50, pp. 910-953, 1960. 


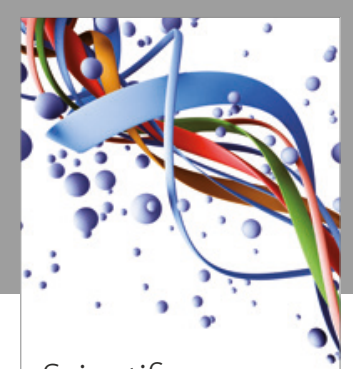

Scientifica
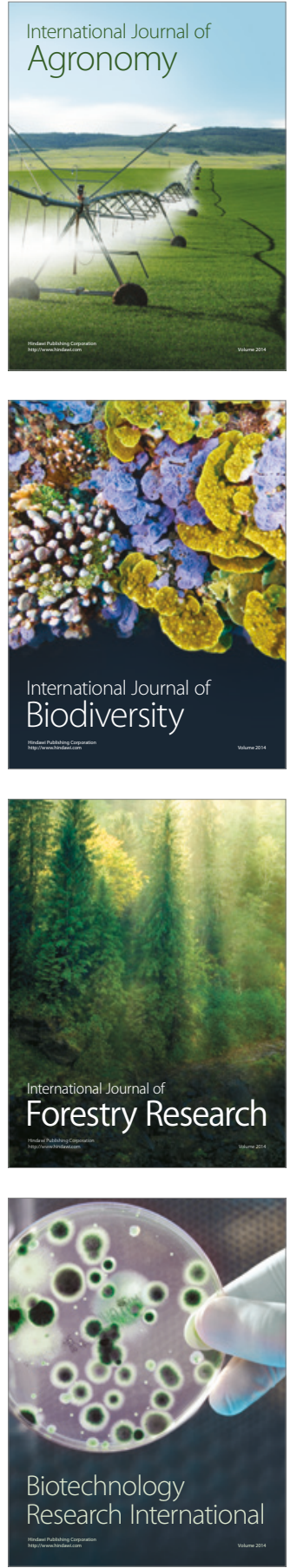
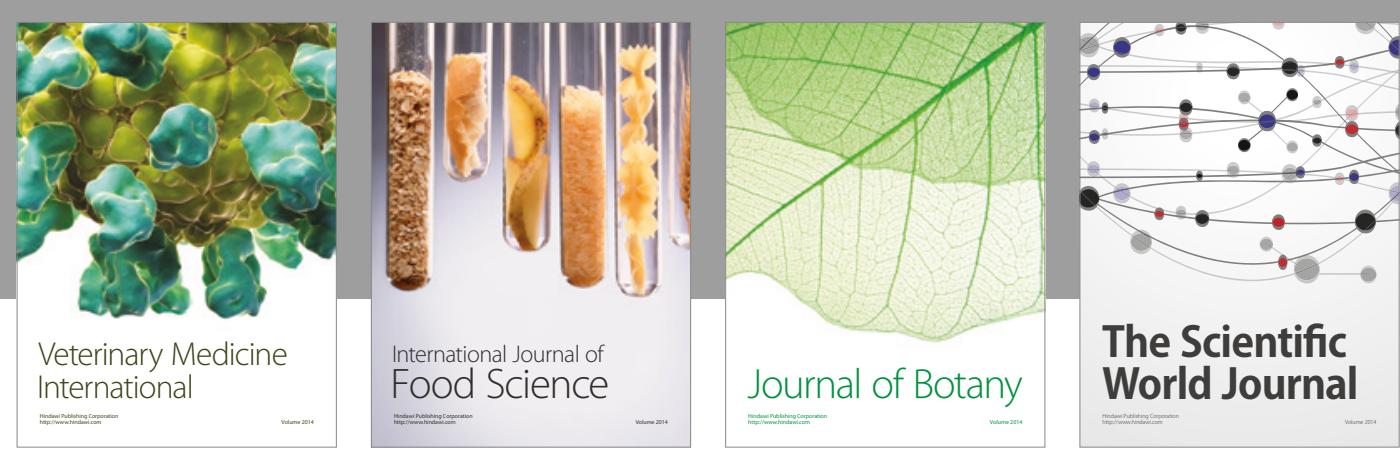

The Scientific

\section{World Journal}

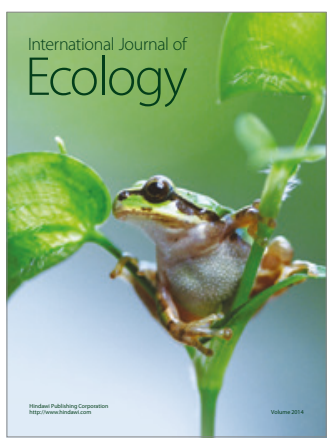

\section{Hindawi}

Submit your manuscripts at

https://www.hindawi.com
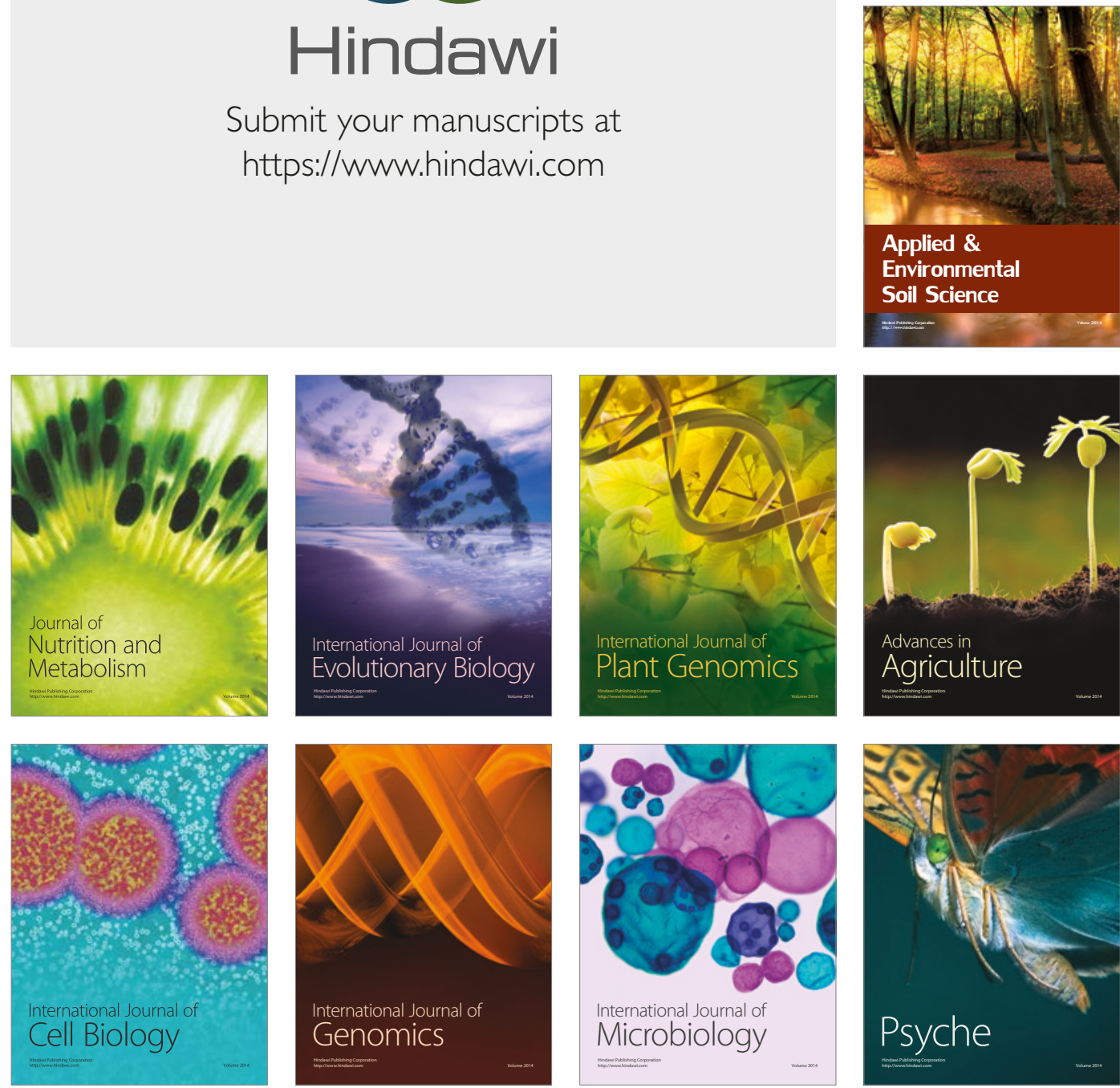

hternational Journal of Microbiology
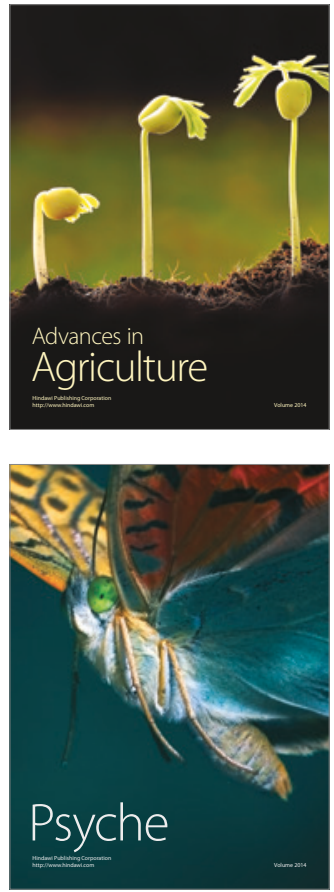